Article

\title{
The New Internationalists: World Vision and the Revival of American Evangelical Humanitarianism, 1950-2010
}

\section{David King}

Memphis Theological Seminary, 168 East Parkway S, Memphis, TN 38104, USA;

E-Mail: dking@memphisseminary.edu; Tel.: +901-458-8232

Received: 26 July 2012; in revised form: 13 September 2012 / Accepted: 19 September 2012/

Published: 8 October 2012

\begin{abstract}
International relief and development agencies consistently rank among the largest evangelical organizations, and in recent decades, they have gained increased exposure and influence within the greater humanitarian community. World Vision, the largest evangelical agency, is also the largest Christian humanitarian organization in the world. Themes of politics and culture wars have led many to scholars to categorize American evangelicals into distinct conservative and liberal parties. Yet the history of American evangelicals' humanitarianism demonstrates how they often resisted such dichotomies. As evangelical humanitarian agencies expanded exponentially over the past five decades, they came to embrace a "holistic gospel" that helped shape evangelical mission debates concerning the relationship between evangelism and social action; they engaged international evangelicals that forced Americans to reconsider their own categories; and many modeled a practical ecumenism that allowed evangelicals to expand beyond a limited subculture to work alongside other religious and even secular NGOs. While other evangelical progressives fragmented over identity politics or remained tethered to small alterative communities, the leading aid agencies have achieved broad support across evangelicalism, making them some of the most influential voices.
\end{abstract}

Keywords: American evangelicalism; evangelical; World Vision; progressive Christianity; humanitarianism; evangelical missions; relief and development; global Christianity 


\section{Introduction}

American evangelicalism is always changing. Both evangelical insiders and outsiders are increasingly recognizing the movement's long-standing internal diversity that limits any attempt at defining the evangelical perspective on a particular issue [1,2]. While social conservatism remains fairly entrenched within American evangelicalism, at the same time, a cottage industry of books and op-eds has emerged in recent years touting the rise of the "new evangelicals" [3-6]. Surveys demonstrate that while younger evangelicals consistently oppose abortion, they no longer fall lockstep behind other traditional markers of social conservatism. Instead, many within a younger generation are just as apt to follow broader societal shifts around issues of sexuality and media consumption. Fewer are interested in becoming culture warriors and more eschew partisan politics. Yet, that does not mean they have retreated into a privatized faith. They are often eager to employ their faith publicly to fight against global poverty and sex trafficking or for creation care and immigration reform [6-8].

These impulses may be most evident through observing evangelicals' embrace of a broad global humanitarianism. New York Times editorialist Nicholas Kristof labeled evangelicals the "new internationalists" [9]. In the wake of Religious Right politics and domestic culture wars, Kristof found their international forays refreshing. He chastised his "secular liberal" readership for relying on outdated and overarching stereotypes, and he highlighted leading evangelical humanitarian agencies like World Vision, International Justice Mission, and Food for the Hungry as examples of agencies that have achieved broad popular support among evangelicals as well as the respect of their professional peers [10,11]. Evangelicals appreciated the attention. While they disputed any claim that their interest in global and social issues was new, they agreed that evangelicals were developing a "deepening social conscience" [12].

Historians have often narrated the rapid rise and fall of an evangelical left in the 1960s and 1970s. Voices like Sojourners' Jim Wallis, Evangelicals for Social Action's Ron Sider, and Oregon Senator Mark Hatfield chastised what they saw as American evangelicals' wholesale endorsement of traditional American conservatism. In an effort to avoid being pigeon-holed within conservative/liberal dichotomies, they often labeled themselves "progressives" that sought to persuade fellow evangelicals to adopt a social and political agenda that prioritized concerns of economic justice, anti-militarism, and racial reconciliation. While always a minority within the larger evangelical movement, they remained a vocal one. By 1980, however, identity politics fragmented progressive evangelicals' efforts at a united vision. Soon the Christian Right had captured the bulk of public attention [13,14].

Evangelical humanitarian agencies flourished in the 1970s just as progressive evangelicals were finding their voice. Yet, as the Christian Right undercut progressive evangelicals' political and social platform domestically, international humanitarianism continued to expand. Evangelical relief and development agencies grew among broad evangelical constituencies, received increased government funding, as well as partnered alongside a diverse international civil society. They avoided the culture wars at home as they promoted relief and development abroad. In so doing, they resisted labeling themselves as a part of an evangelical left or Christian Right. Instead, they positioned themselves as a popular voice with support across the theological spectrum in hopes of uniting a broad evangelical center. Such an approach allowed them to exceed the reach of other progressive evangelicals in turning the attention of a large segment of American evangelicals toward global humanitarianism. 


\section{International Humanitarianism within American Evangelicalism}

With the attention scholars and journalists have paid to American evangelicals' political and theological wrangling, they often overlooked the impact of international humanitarianism. For every dollar evangelicals spent on political organizations, they invested twelve dollars toward foreign missions and international aid. Among evangelical mission agencies, six of the seven largest are now relief and development organizations $[15,16]$. These agencies have grown to become highly influential as the broader field of global development has come to appreciate their size, experience, and expertise $[17,18]$. Four of the top ten largest international non-governmental organizations (INGOs) are evangelical agencies. Among these, World Vision remains the largest. Founded in 1950 as a small American evangelical agency with a mission of evangelism and orphan-care in Asia, it now has offices in nearly one hundred countries with 40,000 employees and an annual budget of 2.6 billion dollars to provide emergency relief, community development, and advocacy alongside the world's poor and oppressed. It takes its mission "to promote human transformation, seek justice and bear witness to the good news of the Kingdom of God" not only to individual child sponsors and megachurches but also in boardrooms of corporate donors, in front of the United Nations, and on Capitol Hill [19].

The rise of evangelical international aid agencies focused greater attention on global humanitarianism; it also helped shape American evangelicals' self-identity. In the American context, many twentieth-century evangelical Protestants defined themselves in opposition to modernism's social gospel, but the story has never been so simple. As evangelical missions mushroomed in size and market share, they debated the relationship between evangelism and social action. Some reconsidered self-imposed boundary lines that had previously prevented cooperation across ecumenical or secular divides. Such debates over evangelical identity demonstrated the effect global dynamics played on American evangelical Protestants. Too often scholars have interpreted American evangelicalism almost entirely as a domestic movement. As mission and aid agencies exposed Americans to global need, they transformed a number of identities at home. Over time, many evangelical agencies shifted their primary emphases away from evangelism and church planting to include relief and development. They promoted a new stream of evangelical humanitarianism that appealed to a broad theological and political spectrum. By the twenty-first century, a new message of humanitarian concern succeeded in shaping American evangelicalism precisely because its new global perspective transcended traditional Western dichotomies such as "evangelicalism and ecumenism" or "evangelism and social action".

While a number of evangelical humanitarian agencies helped shape this phenomenon, this article will highlight World Vision, the largest and arguably most influential evangelical relief and development organization. Its history demonstrates the impact of evangelical humanitarian organizations on the evolving self-identity of a growing strand of American evangelical Protestantism.

\section{Defining Evangelicalism}

World Vision's origins are deeply rooted among American evangelicals-a group that has proven difficult to define. Among historians, David Bebbington's definition remains the most cited. In naming evangelicals' shared commitment to the authority of the Bible, the necessity of conversion, the atoning 
work of Christ, as well as evangelism/activism, Bebbington's definition demonstrates the broad theological commonalities among evangelicals [20]. Yet theological unity - to the extent that it marks the movement - often masks real sociological and cultural differences. Other definitions have sought to add more historical specificity, grounding the "evangelical movement" in the common origins of the global networks emerging from the Great Awakenings of the eighteenth and early nineteenthcenturies $[21,22]$. These additional historical frameworks help, but they still often lead to descriptions of evangelicalism as a monolithic category.

In tracing World Vision's story, I acknowledge that I am limiting my study to one corner of a diverse global evangelicalism. I am focusing on a post World War II evangelicalism that emerged out of a particularly American and Protestant context. While World Vision's story is a global one, I am focusing on how the organization's internationalization and engagement with an increasingly diverse global Christianity shaped the self-understanding of a number of American evangelical Protestants.

World Vision emerged out of the particular self-designated "neo-evangelical movement" of the 1940s. Historian George Marsden has described these neo-evangelicals as a transdenominational network of leaders, institutions, and publications sharing common norms of behavior, history, and culture. [23]. In the nineteenth century, a loose American evangelical movement formed around a common penchant for revival and reform. Camp meetings and voluntary societies propelled this impulse at home while thousands of men and women carried a confidence in Christianity's expansion overseas [24]. Yet by the 1920s, the Fundamentalist-Modernist controversy marked the fracture of the Protestant evangelical consensus. By the 1940s, a coalition of "neo-evangelicals", symbolized by the National Association of Evangelicals and their slogan, "Cooperation without Compromise", sought to reclaim the term. At best, this network of neo-evangelicals remained a diverse and loose coalition. ${ }^{1}{ }^{2}$ While disagreeing on any number of subjects, they shared a commitment to reengage mainstream culture, restore a Christian America, and regain the social standing of traditional Christianity as they understood it. Such commitments led them to define themselves in contrast to separatist fundamentalists. But it also preserved a boundary between themselves and ecumenical Protestants, for many years the so-called "Mainline", who symbolized for them the dangers of deviation from orthodoxy and the elevation of political over spiritual aims.

1 The continual debate of evangelical definition has raised the larger question of whether unity or diversity should serve as the dominant image of evangelicalism in America. Timothy Smith has described evangelicals as a kaleidoscope or mosaic. Randall Balmer prefers the image of a "patchwork quilt" in order to capture a diverse yet folksy evangelicalism [25,26].

2 Another debate centers on whether evangelicalism is described best as a primarily an intellectual, doctrinal movement or as a populist religious tradition. This debate has been fought most clearly between George Marsden and Donald Dayton. George Marsden sees the Reformed tradition at the heart of the evangelical story. Timothy Smith and Donald Dayton view it as predominantly Arminian or "pentecostal", emphasizing the activity of Methodists, Pentecostals, and the host of Revivalist (almost arminianized) Calvinists. (Dayton's "pentecostal" is for Methodists, holiness, Pentecostals alike - and doesn't just fit the heirs of Azusa street.). Dayton has accused Marsden of overemphasizing the Reformed tradition to the exclusion of a more populist evangelical movement. Scholars such as Joel Carpenter and more recently Matthew A. Sutton serve to model a more intermediate position that demonstrates a more fluid overlap between these diverse traditions [27-33]. 
This initial coalition, however, remained short-lived as evangelicals continually redrew their boundary lines [34]. By the 1970s, evangelicalism lost much of its definitional precision as it outgrew the original neo-evangelicals' hope for a united movement, fracturing instead into a number of smaller interest groups. In the late 1960s and 1970s, a new generation of evangelicals sought to expand the movement in new directions. One group emerging from this second generation were the leaders of a small "progressive" evangelical movement. Initially, labeled "young" or "radical" evangelicals, they sought to challenge fellow evangelicals to accept responsibility for social issues, theological dialogue, and political awareness. By the 1980s, many evangelicals had accepted the challenge to enter the public sphere, but the conservative political and social agenda of the Religious Right outdistanced the public attention given to the diverse consortium of progressive evangelical causes.

Historian Nathan Hatch may have best defined evangelicalism not through shared doctrine or practice but more as a movement with a particular cultural style. For Hatch, evangelicalism succeeded through its "entrepreneurial quality, its populist and decentralized structure, and its penchant for splitting, forming and reforming" [35]. The past decades have only led to further fragmentation and diversity. Yet, even if evangelicals often failed to agree on a single vision for their movement, in navigating shifting evangelical boundaries they invested the term "evangelicalism" with various meanings. The evolution of American evangelicalism's mission and humanitarian agencies illustrated the internal diversity of evangelicalism. Few explicitly employed terms like "progressive", but many served at the leading edge among evangelicals' efforts to apply their faith to social injustices.

\section{Evangelical Missions in the 1950s}

As the "neo-evangelical" movement gathered steam in the wake of World War II, it applied its optimism in reengaging and restoring a Christian America to a renewed optimism in evangelizing the world. At the beginning of the twentieth century, American missionaries had become popular and powerful, and the mission movement united across theological lines to bring conversion and civilization to the world. The 1910 Edinburgh Conference embodied this enthusiasm "for the immediate conquest of the world" and the "evangelization of the world in this generation" [36].

Yet, the first half of the twentieth century led to changes within the missionary enterprise. By World War I, the appeal of Edinburgh's watchword began to falter. Influenced by modernism and the social gospel, some missionaries in the dominant mainline denominations measured their success through the building of hospitals and schools rather than the counting of souls saved. Others adopted a broader internationalist language and reevaluated their view of non-Christian religions. While missions continued to grow slowly in the 1920s and 1930s, these new directions shattered the united missionary enterprise [37,38].

The fundamentalists and modernists of the era exported their theological battles to the mission field [39]. Fundamentalists withdrew from denominational mission boards to form their own independent mission societies. From their perspective, if the mainline had abandoned evangelism for ecumenism and social action, they must remain true to their calling. They formed specialized agencies to evangelize the unreached. For decades, mainline missionaries continued to dominate in numbers and resources, but by 1955 the combined numbers of evangelical and fundamentalist missionaries became the majority $[40,41]$. 
As postwar evangelical missions grew, they sought to distinguish themselves from their mainline competitors. They promoted evangelism, not social action, as their sole end. Yet, some neo-evangelicals did not abandon the need for a social ethic. In 1947, Carl F. H. Henry, the preeminent evangelical theologian of his generation, penned his Uneasy Conscience of Modern Fundamentalism [42]. He lamented that the liberal social gospel had abandoned belief in biblical supernaturalism and individual salvation, but he feared that fundamentalists' revolt "against the Social Gospel" had led to a "revolt against the Christian social imperative". If they ignored a social ethic, they would forfeit their right to be heard as agents of the gospel [43].

Henry called his fellow evangelicals to rediscover the implications of the gospel for the "political, economic, sociological, and educational realms, local and international" [44]. He highlighted nineteenth century evangelicals' support of abolition, temperance campaigns, and rescue missions to illustrate the not so distant evangelical social ethic he hoped to revive [45]. Yet, he continued to insist evangelism remained primary over social action while individual regeneration served as the key to lasting societal transformation [46]. Without specific recommendations, Henry's manifesto served more as a clarion call rather than a plan of attack.

The primacy of evangelism continued to serve as a boundary marker that evangelicals used to distinguish themselves from mainline missions. It also distinguished them from the newer religious humanitarian agencies that focused on large-scale relief. The "three faiths consortium" of mainline Protestants, Catholics, and Jews had begun to establish ties with the U.S. government to facilitate their humanitarian efforts. Religious philanthropies such as Catholic Relief Services (1943), Church World Service (1946), Lutheran World Relief (1945), and the American-Jewish Joint Distribution Committee (1914) dominated private and public support to rebuild Europe in the 1940s and continued into the Cold War theaters of Korea and Vietnam as they delivered government donated food, surplus goods, and equipment overseas [47,48].

The largest religious humanitarian agencies served as arms of denominational or ecumenical bodies, but they included few evangelicals. One exception was World Relief. In 1944, the National Association of Evangelicals established the War Relief Commission to transport food and clothing to displaced Europeans; they renamed it World Relief in 1950, hoping to offer both material and spiritual goods. World Relief funded humanitarian projects: hospitals, orphanages, and widow homes. It also shipped surplus food and clothing overseas. The agency registered to receive government aid in 1956 and grew modestly in size but worried about the risk of minimizing evangelism. In each shipment, recipients would always find Bibles and religious tracts [49]. Its limited size and evangelistic proclivities left World Relief on the periphery of humanitarianism's inner circle. Most evangelicals viewed missions and humanitarian aid as separate spheres, and the former still captured the bulk of their attention.

Even as these evangelical boundaries remained strong, a new breed of independent evangelical agencies emerged to bring attention to suffering overseas. World Vision was one of the earliest. Youth for Christ evangelist Bob Pierce, initially encountered global poverty on his evangelistic crusades to Asia. He founded World Vision in 1950 at the onset of the Korean War to supply emergency resources to Korea's hospitals, schools, and orphanages. While it did not send out its own missionaries, neither did it function as an established relief agency. World Vision was a "missionary support organization" 
that Pierce insisted served merely as a bridge between American evangelicals at home and missionaries overseas.

Theological conservatives trusted Pierce because of his fluency with the evangelical vernacular. Coming of age alongside the likes of Billy Graham, Campus Crusade's Bill Bright, and the Navigators' Dawson Trotman, he joined a generation of religious entrepreneurs eager to reestablish evangelicals as the custodians of a Christian America and a revived internationalism. He saw evangelical missions in Asia as the hinge-point for God's work in the world, a site of both political and spiritual advancement. He also encouraged evangelicals to meet immediate physical needs while avoiding the liberals' language of "structural sin" and "social salvation" that conservatives despised. He brought back firsthand footage of his travels in China, India, Korea, and Vietnam, and he listed the atrocities he encountered: hundreds of Christians martyred, more than one and a half million homeless, 12,000 villages flattened. But his appeals for support turned on stories and images of immediate, individual need: feed this Christian widow, build a shelter for this family, and provide medicine for a missionary's leprosy clinic.

By 1953, Pierce introduced the concept of "child sponsorship". For ten dollars a month, Americans could support an individual Korean orphan. The image of the innocent child bypassed divisive theological debates. How could American sponsors exchange photos and letters with their "foster" child and oppose efforts to meet their immediate needs? Child sponsorship soon became the backbone of World Vision's fundraising as it financed hundreds of missionary orphanages. While the Christian Children's Fund (CCF) [50], the newly formed Everett Swanson Evangelical Association (later renamed Compassion International) [51], and many other upstart agencies also relied on child sponsorship, World Vision soon came to dominate this new brand of evangelical mission.

Yet, from the beginning, World Vision faced tensions over its identity. Mainstream relief organizations dismissed World Vision's relatively miniscule size and sectarian evangelical theology, but as an evangelical missionary organization, World Vision operated in a different context. Fraternizing with ecumenical mainline Protestants, much less Catholics, Jews, or secularists was anathema. Flirting with humanitarian organizations also bordered upon promoting social welfare at the expense of evangelism. Yet, Pierce also faced internal critiques within the evangelical subculture as World Vision's humanitarian work pushed against traditional evangelical boundaries. It spoke an evangelical language but added new accents that made more than a few people uncomfortable.

\section{An Evolving Evangelicalism, 1960s-1970s}

\subsection{Establishment Evangelicals [52]}

By 1960, more established neo-evangelicals led by the likes of evangelist Billy Graham, theologian Carl Henry, and pastor Harold Ockenga sought to solidify their success by positioning themselves as America's mainstream faith in contrast to a "militant fundamentalism" or a "compromising ecumenism". The circulation numbers of evangelical standard-bearer Christianity Today now outdistanced its mainline rival, the Christian Century [53]. Polls showed more Protestant ministers identified as conservative over liberal while more American evangelicals achieved higher levels of education and social status [54]. Affluence brought higher giving, which produced increased budgets 
and building programs. In the burgeoning Sunbelt region, new evangelical churches sprouted everywhere [55]. Nationally, parachurch agencies like Campus Crusade, the Billy Graham Evangelistic Association (BGEA), and World Vision expanded dramatically [56]. As a result, their rhetoric changed. Evangelicals now saw themselves less as outsiders and more as mainstream Americans with a voice in the public square.

Yet, American evangelicals still fretted over encroaching adversaries that were leading to a decade defined by "riots, revolt, and revolution" [57]. At home, they worried over secularism and a growing counterculture. Abroad, they feared communist expansion in conflicts like Vietnam [58]. In the 1960s, evangelicals lamented that no enterprise was "so thwarted and threatened by forces all around it as the missionary venture" [59]. As new nations threw off colonial powers, many closed their doors to Christian missionaries whom they saw as symbols of religious and Western cultural superiority. Many evangelical missionaries recognized a need for humility in order to earn the right to be heard in a postcolonial world, but they stood firm on saving the unconverted as the one non-negotiable of the missionary enterprise.

What they lamented as the loss of missionary concern in the 1950s-60s, however, was perhaps more a transfer of allegiances. Still intent on "saving the world", American Christians substituted relief and development for evangelization. The number of mainline missionaries continued to decline even as religious humanitarian agencies mushroomed. Mainline Protestant and Catholic agencies remained the major conduits for U.S. foreign assistance as relief and development became a tool of statecraft. With the percentage of federal aid often comprising over half of the annual budgets of the leading humanitarian agencies, the smaller evangelical agencies knew resisting government partnership handicapped their efforts to expand [60]. But they worried that federal aid would lead to the compromise of their religious identity by taking the priority away from evangelization.

World Vision continued to live within these evangelical tensions. By the early 1960s, it began to receive limited government subsidies and commodities to distribute overseas, but out of a concern to maintain its evangelistic commitments, federal aid remained a fraction of its operating budget. Among fellow American evangelicals, the occasional mission executive questioned World Vision's balance between humanitarian aid and soul-saving, but founder Pierce continued to persuade his evangelical base through his typical folksy piety: "You can't preach to people whose stomachs are empty. First, you have to give them food" [61]. He avoided parsing theological details, rather he wanted evangelicals to house refugees and feed the hungry, as well as evangelize the world, and he presented World Vision as a means to do it all.

\subsection{The Rise of a Progressive Evangelicalism}

By 1970, many establishment evangelicals felt they had achieved a portion of the culture-shaping power and prestige they craved. Evangelicals had captured the attention of mainstream media willing to point to signs of American evangelicalism's rise: Billy Graham's close relationship with President Richard Nixon, national bestsellers like Kenneth Taylor's The Living Bible and Hal Lindsey's Late Great Planet Earth, and local television fixtures like Robert Schuller's "Hour of Power" (1970) and Pat Robertson's “700 Club” (1962) [62]. 
Success, however, could not mask internal divisions. As early as 1967, Carl Henry, the founding editor of Christianity Today feared that evangelicals stood "at the brink of crisis" [63]. Some sought entrée among the nation's conservative establishment in order to portray evangelicals as conservative Republicans. A new minority hoped to take the movement in the opposite direction. Nowhere was the divide more evident than on college campuses. Between 1960 and 1972, the proportion of evangelicals with a college education tripled. Having come of age in the turbulent 1960s, some of these "younger evangelicals" came to challenge the evangelical establishment [64]. Afraid evangelicalism was becoming nothing more than cultural Christianity, these self-described progressive evangelicals complained of a lack of concern for social justice and an unquestioned acceptance of American civil religion.

Establishment evangelicals claimed they prioritized evangelism to oppose a "compromising ecumenism", but the young evangelicals saw it as bartering their social conscience for a pottage of world affirming, middle class privilege. In 1970, the triennial Urbana mission convention of the Intervarsity Christian Fellowship (IVCF) gathered twelve thousand students around the theme of "Christ the Liberator". Speakers discussed Vietnam, revolution, race, and poverty. Many nodded as Peruvian Samuel Escobar challenged the "middle-class captivity" of American evangelicalism [65]. They stood and cheered as black evangelist Tom Skinner preached that "any gospel that does not want to go where people are hungry and poverty-stricken and set them free in the name of Jesus Christ-is not the gospel" [66,67]. Elder evangelical statesman Carl Henry agreed that "the time is overdue for a dedicated vanguard to move evangelical witness to frontier involvement in the social crisis". He worried that if evangelicals avoided social issues, they would lose the coming generation [68].

A number of young professors agreed and began criticizing the lack of social concern in evangelical publications. Marquette sociologist David Moberg urged evangelicals in The Great Reversal: Evangelism versus Social Concern (1972) to consider not only individual but structural sin. Indiana State University historian Richard Pierard's The Unequal Yoke: Evangelical Christianity and Political Conservatism (1970) and Calvin College ethicist Richard Mouw's Political Evangelism (1973) criticized the evangelical equation of Christian values with political conservatism. Young evangelicals absorbed these popular books, and many flocked to study under teachers who saw the social implications of the Christian scriptures [69].

The movement attracted activists as well as academics. One among several new evangelical communities, Jim Wallis led a group of students from Trinity Evangelical Divinity School to call themselves the People's Christian Coalition [70]. While they criticized American social injustices broadly, the Vietnam War became a central concern. In 1970, most evangelicals could see that America was failing in Vietnam, but they refused to abandon their patriotic ardor. Billy Graham's July $4^{\text {th }}$ sermon at the Lincoln Memorial affirmed the majority evangelical view: America had opened its doors to the alienated and oppressed, shared its wealth and its faith, and always refused to use its power to subjugate other nations. In his aptly named magazine, The Post-American, Wallis took the opposite tact. He labeled America as an evil empire and claimed the church's cultural captivity caused it "to lose its prophetic voice by preaching and exporting a pro-American gospel and a materialistic faith which supports and sanctifies the values of American society" [71].

These self-described evangelical progressives represented a minority, and they rarely spoke with a common voice. They taught in universities, lived in alternative communities, and organized political 
action committees. In 1973, fifty leaders came together over Thanksgiving weekend at an inner city Chicago YMCA to discuss evangelical social responsibilities. They renounced those who dismissed the need for evangelism as well as those who wedded the church to conservative middle-American values. The resulting Chicago Declaration called for economic justice, peacemaking, racial reconciliation, and gender equality [72]. Their manifesto received broad coverage in the religious and secular press. The Washington Post reported that it "well could launch a religious movement that could shake both political and religious life in America" [73]. At the least, it demonstrated the surfacing of a progressive evangelical voice. Few American evangelicals were willing to endorse the progressives' platform fully, but many were more open to new perspectives. ${ }^{3}$ In the wake of the Civil Rights movement, the Vietnam War, and the Watergate scandal, some evangelicals recognized they could no longer call for evangelism to the exclusion of social engagement. They also began to question an American exceptionalism that overlooked a growing internationalism.

\subsection{Evangelical Missions}

At the same time, American evangelicals also realized the missionary enterprise was taking new directions. For many, the dichotomy between saving souls and feeding bodies no longer made sense, and they recognized it had skewed their global vision. They had heard critiques from young progressive voices at home, but experience overseas was even more persuasive. Alongside career missionaries, larger numbers of American evangelicals were traveling for the first time overseas. New programs like Wheaton College's Human Needs and Global Resources (HNGR) sent students for field-based service learning around the world. Both the Christian and mainstream press brought increased coverage of global events into American homes. In magazines like Christianity Today, World Vision, and InterVarsity's His, global evangelical voices reminded American readers of the Old Testament prophets' calls for justice as well as Jesus' feeding the poor and healing the sick. Evangelicals were no longer willing to let the mainline build the schools and hospitals and feed the hungry. As one missionary put it: "too often we have rushed by the hungry ones to get to the lost ones" [75]. If evangelicals were to gain a hearing overseas, they must attend to the realities of worldly deprivation and injustice. But how was still up for debate.

In July 1974, 2700 evangelicals from 150 countries convened the International Congress on World Evangelization in Lausanne, Switzerland. This "Lausanne Congress" served as a high water mark for setting the direction of a global evangelical identity and missionary motivations [76]. With half the delegates coming from the global South, it proved that evangelicalism was now a global phenomenon. It also represented an unprecedented international evangelical statement on the need for Christians to resist poverty, hunger, and injustice. Yet, it continued to leave open the question of how to explain the relationship of social action and evangelism [77].

During the Congress and the subsequent "Lausanne movement", discussion of missionary method seemed to travel in two directions. Western leaders still set much of the agenda as the church growth

3 Few establishment evangelicals demeaned the Chicago Declaration. In fact, Billy Graham, in a post-Watergate interview with Christianity Today claimed, "We have a social responsibility, and I could identify with most of the recent Chicago Declaration of Evangelical Social Concern. I think we have to identify with the changing of structures in society and try to do our part" [74]. 
movement led by Fuller Seminary professors Donald McGavran and Ralph Winter took center stage. Their concept of "unreached people groups" focused on the research and techniques necessary to fulfill their first priority, evangelizing the world. In contrast, new and persuasive voices from Two-Thirds World evangelicals preached of the necessity for both evangelism and social concern without the dichotomies framed by Western Christians. The Latin American theologians Samuel Escobar and René Padilla made the biggest splash at Lausanne when they denounced American evangelicalism as "a cultural Christianity" that equated faith with the American way of life as well as a "disembodied faith" that saw the gospel merely as a spiritual message [78]. While Western evangelicals left Lausanne acknowledging that they must care about the body as well as the soul, Escobar and Padilla felt they had only scratched the surface. In spearheading an alternative manifesto on "Radical Discipleship", endorsed by almost a fifth of Lausanne delegates, they affirmed that the gospel included liberation, restoration, wholeness, and "salvation that is personal, social, global, and cosmic" [79,80].

After Lausanne it was fair to ask: Would evangelical missions continue to be a united movement?" [81,82]. The dominant group consisted of those who sought to use Lausanne as the platform for world evangelization. In 1980, the follow-up Consultation on World Evangelization (COWE), in Pattaya, Thailand, gathered over 900 attendees to form strategies for the evangelism of unreached peoples while leaving social action off the agenda [83].

That same year, ethicist Ron Sider, a respected progressive evangelical voice, convened a smaller group for an International Consultation on Simple Lifestyle. They called evangelicals to suffer with the poor by pledging "to live on less and give away more". In moving beyond past evangelical statements of social concern, they labeled some social structures as evil and criticized Western overconsumption [84].

Two years later, at the 1982 Lausanne Consultation on the Relationship between Evangelism and Social Responsibility (CRESR) in Grand Rapids, Michigan, both sides sat down to mediate this growing rift within evangelicalism. What was the relationship between social action and evangelism? They fell short of providing a definitive solution, but they agreed both were a necessary part of the gospel. Most evangelicals realized they must move beyond either-or debates $[85,86]$.

\section{An Emerging Evangelical Humanitarianism}

\subsection{World Vision's Evolving Evangelical Identity}

While only a slim minority subscribed outright to the proposals of self-styled "evangelical progressives", the majority of evangelicals affirmed the need for missions to address social concerns alongside personal evangelism. In the past, agencies like World Vision sometimes felt its humanitarian work pushed it to the evangelical fringes, but by the early 1970s, it now felt that it represented the mainstream of both evangelical missiology and popular opinion. In fact, as one World Vision executive reflected after Lausanne: "The emphasis on social action ministries hand in hand with evangelistic outreach put World Vision in a unique catalytic and leadership position in Evangelical Christianity" [87].

Yet, if some saw World Vision as part of the evangelical center, it was no longer the same organization. Founder Bob Pierce feared that professionalization, government funds, and technical 
advances would lead World Vision to temper its evangelical mission. By 1967, he had resigned. In its second generation, the organization did not abandon evangelism, but it began to focus more attention toward relief and development. It had always provided emergency relief through missionaries and local Christian communities, but high profile disasters in the early 1970s prompted the organization to take on larger challenges. In 1970, it moved into East Pakistan (now Bangladesh), which had suffered from a massive cyclone, tidal wave, and civil war that left 500,000 dead and created ten million refugees. In 1972, it received its first large government grant to coordinate relief after a devastating earthquake in Nicaragua. In Africa, it launched programs to feed people during famines in Biafra (Nigeria) and Ethiopia. By the end of the decade World Vision referred to its employees no longer as missionaries but as aid-workers. While World Vision insisted that all employees profess a Christian faith, fewer now came with degrees from evangelical seminaries or Bible colleges without further training in fields such as public health or agricultural engineering.

New activities led World Vision to recruit staff from a new evangelical generation. For example, in 1977, Arne Bergstrom came to work for World Vision. While he heard Billy Graham and Bob Peirce at Youth for Christ rallies as a child and attended Bethel College, he resisted the evangelical subculture. He participated in the antiwar and Civil Rights movements, and he pursued graduate education in sociology at Marquette. He hoped to work overseas but not as a traditional missionary. In churches, all he ever heard missionaries mention was "soul-winning", and he found such language hollow without work for social change. As he saw it, among evangelical organizations, only World Vision offered an outlet to apply his faith to the world's problems [88]. Despite its success among the evangelical establishment, World Vision also appealed to the "young evangelicals" eager to solve social problems and recalibrate the direction of American evangelicalism.

New activities also led to new dialogue partners. In the 1970s, World Vision was still more missionary agency than humanitarian NGO, but interactions with foreign governments as well as other ecumenical and secular NGOs exposed it to new vocabularies that slowly began to chip away at its insular evangelicalism and unquestioned support of American exceptionalism. It also realized that Americans were no longer at the center of evangelical demographic or institutional growth, which had shifted to the global South [89]. World Vision's own non-Western field personnel complained of paternalistic and controlling tendencies. As a result, it began to rely less on American expatriates and more on an indigenous workforce while also reorganizing to share leadership internationally. In contexts like Lausanne, World Vision leaders often claimed they had more in common with the holistic gospel advocated by many "Two-Thirds World" evangelicals over against the strict dichotomies of Western Christians. World Vision still claimed an evangelical identity, but it often found American evangelical boundaries constricting. So, it broadened the boundaries.

American evangelicalism reached new heights as presidential candidate Jimmy Carter declared himself "born-again" and Newsweek declared 1976, "The Year of the Evangelical". Yet, in many ways, evangelical growth had splintered the movement. Evangelical elder statesmen Carl Henry lamented that the "evangelical lion is nonetheless slowly succumbing to an identity crisis" [90]. In politics, a few evangelicals called for America to repent from militarism, consumerism, and neo-colonialism at the same time a Christian right, popularized by the Virginia Baptist Jerry Falwell, organized "I Love America" tours around the country to combat secular humanism, pornography, abortion, and homosexuality. In theology, evangelicals fought over biblical inerrancy as some 
evangelicals feared popular growth would compromise their distinctive theological positions. Christianity Today editor Harold Lindsell's Battle for the Bible labeled the doctrine of biblical inerrancy non-negotiable, and called out any "so-called" evangelicals who disagreed [91,92].

If World Vision could not altogether avoid the internal divisions within American evangelicalism, it tried to stay above the fray. The organization's second president, Stan Mooneyham, deplored his fellow evangelicals' penchant for rigid categories. He argued the world was gray, "one man's evangelical may be another man's liberal" [93]. After spending most of his year in war-torn Southeast Asia or drought-stricken Africa, he found disputes over school textbooks or the legitimacy of the Revised Standard Version petty. While others argued, he said that World Vision would do one thing: feed the poor in Jesus' name [94].

World Vision was not naive to the potential pitfalls in negotiating diverse evangelical constituencies. It avoided the idealism of both left and right for a pragmatism that sought to take its message to the masses. While evangelicals developed a growing interest in a wider variety of global issues and events, World Vision increasingly presented itself as a humanitarian organization that spoke with an evangelical accent to expose its American audiences to global need. ${ }^{4}$

\subsection{World Vision and World Hunger}

To commemorate its twenty-fifth anniversary, World Vision designated 1975 as a year-long emphasis on world hunger. It announced Project FAST (Fighting Against Starvation Today) to raise funds and public awareness. Since the 1960s, relief agencies had provided emergency aid for famine victims in North Africa's Sahel region. With the famine at its height in 1972 to 1974, newspapers shocked Western readers with images of malnourished African children.

World Vision enlisted Oregon Senator Mark Hatfield, a recent addition to its board and leading figure among the progressive evangelicals, as the FAST campaign's honorary chairman. Hatfield had remained a strong critic of the war in Vietnam. With the timetable set for the withdrawal of U.S. troops, Hatfield turned his activism toward world hunger. In Nov. 1974, Hatfield gathered Congressional leaders and reporters to a Capitol luncheon. To their surprise, the meal consisted of nothing more than a few ounces of rice, the 67 caloric average daily intake of the world's hungry. With Mooneyham by his side, Hatfield took the opportunity to announce his partnership with World Vision, "It is my hope the government will respond when it sees that Americans do feel compassion for the millions now starving throughout the world" [96].

The event served as the kick-off to the FAST campaign, and World Vision followed with its own media blitz. Mooneyham and Hatfield fielded interviews from the press and flooded evangelical magazines from Christianity Today to the Post American with articles on hunger. The FAST campaign not only sought to raise funds but also challenged Americans to identify with the hungry. Hatfield realized that "until Americans willingly experience hunger, even on a limited basis, they cannot begin to comprehend the condition ... responsible for the death of more than 10,000 of their fellow men every day" [97]. World Vision developed "planned famine" curricula for local churches so that youth groups could raise funds while fasting for forty hours. The Love Loaf campaign asked families to skip

Evangelical bellwether, Christianity Today, admitted the expansion of the military, aid agencies, global businessmen, and sightseers marked "the comparative shrinkage of foreign missions to small potatoes in our international relations" [95]. 
a meal each week and give the amount to world hunger, distributing small loaf-shaped banks as reminders for families to pray for the hungry at each meal.

World hunger resonated with evangelicals, and World Vision offered them acceptable ways to respond. It allowed them to act, indeed to become social activists within limits. They could provide emergency aid without abandoning evangelism or becoming entangled in unproductive debates about structural change. They could funnel support through mission and parachurch agencies without turning to government programs. World Vision's appeals offered hard facts and statistics, but they made sure that hunger had a face. Playing to emotion and asking for an immediate response, the hungry child became the face of World Vision [98,99].

World Vision emotionalized hunger, but it also began to challenge its American evangelical audiences to move beyond Christian charity. In calling for an "all-out war against world hunger", Mooneyham deemed World Vision as an advocate for the voiceless, "who pleads their case to an overfed, affluent world that seems more concerned with gross national product, megatons and horsepower than it does with human beings" [100]. While evangelicals soaked up Hal Lindsey's prognostications over the end-times, Mooneyham criticized the premillennial eschatology that led evangelicals to reject this world for the next [62]. Defining himself as a Christian humanitarian, Mooneyham said that World Vision viewed the hungry as persons in need of spiritual as well as physical aid. And he added that aid would sometimes require social change. World Vision matured in its understanding of poverty; its appeals were religious, but they also reflected an awareness of the political, economic, and systemic dimensions of hunger.

World Vision also began to introduce structural topics into its language of Christian compassion. Secular or ecumenical agencies it previously labeled as suspect now became partners in a shared mission. World Vision encouraged supporters to bring resources from the United Nations, USAID, and Church World Service into their churches. Layering the systemic and the individualistic into its appeals, it also began to redraw the boundaries lines between sacred and secular [101].

Mooneyham also wanted to expose Americans to global perspectives. For two decades, World Vision had defined its missionary agenda in concert with Cold War anticommunism, and it now acknowledged its previous captivity to American parochialism. Mooneyham dispelled popular myths that the poor were happy and encouraged his audience to consider poverty from the perspective of those in the global South. He argued how divisions once seen as purely ideological were in fact economic. Turning to America's dependence on foreign oil and cheap coffee, Mooneyham demonstrated how globalization made the West complicit in poverty [102].

Before long, World Vision was raising hard questions about the American way of life. It remained hopeful that Western technology could boost food production, but it complained that broken systems created hunger in the midst of abundant resources. Mooneyham echoed Hatfield's pronouncement that the U.S. was far less generous with foreign aid than its citizens believed. But Mooneyham's critique went beyond systems and governments. He told the American public that it shared the guilt. He criticized American over-consumption, challenged Americans to fast in solidarity with the poor, and admonished Christians to join the move toward simple living. "Should not doing good include working for systematic change as well as delivering a Christmas basket, making a contribution on worldwide communion Sunday, or writing a check to the United Way?" [103]. World Vision's fundraising appealed 
to the "compassionate charity" of American Christians, but it began to teach them that charity was not enough [104].

A few progressive evangelicals adopted simple lifestyles, protested structural poverty, and began to question American innocence. Most evangelicals still ignored critiques of American imperialism, demands for structural change, and appeals for simplicity of life, but pleas to feed starving children in the name of Jesus touched their hearts. By 1976, as the worst of the Sahel famine passed and World Vision's campaign ended, the hunger crisis faded from the front pages. But it had put World Vision on the humanitarian map [105]. It had introduced Third World poverty to American evangelicals and made it, for many, a goal of Christian mission. It was helping to change evangelical humanitarianism.

\subsection{The Evangelical Relief and Development Sector Takes Shape}

These campaigns brought increased media attention and more donations from American evangelicals. In the early 1970s, World Vision had begun to bring its religious message to even broader audiences through television. It soon specialized in multi-hour hunger telethons. Throughout the decade, its annual income grew from 4 to 94 million dollars [106]. World Vision's success spearheaded the growth of a new type of evangelical agency: Christian relief and development organizations that operated outside the sphere of evangelical missions. Medical Assistance Program (MAP), World Concern, Food for the Hungry, Institute for International Development, Inc. (IIDI), and others all followed in World Vision's footsteps. With an average annual growth of seventeen percent throughout the 1970s, these new agencies grew at twice the rate of traditional evangelical mission organizations $[107,108]$.

By the 1980s, not only did evangelical relief and development agencies outgrow evangelical missions, they also begin to catch up to the leading mainline and secular humanitarian organizations in size, popularity, and professionalism. Having expanded rapidly, some began to step back to reconsider the theology behind their programs. Progressive evangelicals applauded the turn many agencies were making from one-time relief programs to sustained development. Development privileged the dignity of the local person over paternalism and holistic over dualistic language. Yet some worried that evangelicals' understanding of development - and their presentation of it to others-were steeped in secular language. Perhaps they had embraced it too quickly. In 1977, Ron Sider wrote Rich Christians in an Age of Hunger to encourage evangelicals to live more simply and dive into social issues. Among progressive evangelicals, the book became a cult classic [109]. Sider championed development but acknowledged that "it makes no sense for Christian development agencies to take their basic assumption on the nature of development from secular sources like the United Nations, secular government in developed or developing nations, or private secular development agencies" [110-112].

Evangelicals struggled to define Christian development in theory; they also struggled to incorporate it into the practice of traditional missions. Evangelical relief and development organizations emerged from the same background as the mission agencies, but as the $R \& D$ agencies grew, theological differences as well as various resentments sometimes eroded their natural affinities. Evangelicals in the pews supported the new R\&D agencies; uninterested in the old debates over social action and evangelism, they responded to appeals to help victims of poverty, famine, or war in the name of Jesus. 
But traditional missionary executives worried that the new agencies were co-opting their donor base, and they feared losing funds for evangelism.

In 1979, evangelical R\&D agencies founded their own umbrella organization, the Association of Evangelical Relief and Development Organizations (AERDO) [113]. AERDO member agencies were asking different questions: fostering technical expertise, mutual support, and best practices among its members while also lobbying for government grants. They had evolved from mission agencies that did social service into religiously based relief and development organizations. While the majority of evangelicals now spoke of the need for holistic missions, the new international relief and development agencies most often led evangelicals' efforts to put into practice an international humanitarian agenda.

\section{Going Mainstream: Evangelical Humanitarianism in the 1980s-1990s}

Increased publicity of global disasters, especially in Africa, led to the continued growth of evangelical R\&Ds through the 1980s. In response to the 1984 Ethiopian famine, World Vision's income jumped eighty percent in one year. It raised funds faster than it could create programs to spend them. Along with individual donors, World Vision increasingly began to rely on federal funds that forced the organization to meet greater professional standards for its work [114].

World Vision benefited from the media's growing coverage of international disasters as well as increased interest in American evangelicalism. As the mainstream media "discovered" evangelical growth in the mid-1970s, they often used World Vision as a prime example [115-117]. Yet, as coverage of evangelicals began to hone in on the Religious Right by 1980, World Vision President Mooneyham worried that domestic politics and culture wars would only further divide evangelicals into special interest groups that ignored global poverty. World Vision wanted to be evangelical; it also wanted to be distinctive [118]. One reporter described Mooneyham "as an evangelical but not the type who walks around with a Bible under his arm and invokes the name of the Lord in every other sentence" [119]. The pastor of New York City's mainline Riverside Church, William Sloane Coffin, quipped in 1977: "If you get an Evangelical with a social conscience you've got one of God's true saints" [120]. World Vision hoped it fit the bill.

World Vision pushed the envelope among American evangelicals first by pursuing partnerships beyond traditional boundaries. Forging them was not easy. The humanitarian industry's old guard had little incentive to open its doors to evangelical "upstarts". Yet, by 1985, World Vision had gained consultative status with the United Nations High Commission for Refugees (UNHCR) and the World Food Programme (WFP). A few years later it added the United Nations Children's Fund (UNICEF) and the World Health Organization (WHO) to the list. When Pierce founded World Vision in 1950, few evangelicals trusted the United Nations. By the end of the 1980s, World Vision had made UN initiatives central to its own work, gained a seat at the World Economic Forum in Davos, and even initiated bilateral aid programs with the World Bank [121].

The evangelical-ecumenical divide may have proven even more difficult. Despite World Vision's stated willingness to work across traditional theological boundaries, ecumenical institutions like the World Council of Churches (WCC) still questioned World Vision's theology-accusing it of proselytism and Western imperialist tendencies. Most often the WCC's accusations reflected past rather than present relationships, but the conflicts were often personal, rooted in the history of a family 
feud. By this time, however, World Vision saw itself as a model for practical ecumenism. Often impatient with the slowness of ecumenical dialogue, it leveraged its size and resources to bring diverse voices together. These new voices often pressed World Vision to reposition itself in the midst of a diversifying global Christianity.

In many countries, World Vision was learning to work with and often hire staff outside of its traditional evangelical fold. Its staff began to resemble the Christian communities in the countries where it worked. In expanding to Eastern Europe after the Soviet Union's collapse, it hired a number of Orthodox staff persons. In Latin America, it hired more Catholics. The percentage of Pentecostal staff grew alongside the movement's growth throughout Sub-Saharan Africa. The majority of staff members still identified themselves as evangelical, yet diverse donor and staff constituencies made room for a broader Christian language that no longer reflected only the dialect of an American evangelicalism [122].

In the U.S., World Vision expanded with broad support across the theological and political spectrum. It kept an official distance from the "evangelical left", which by the 1980s had fallen from public interest, but it did not sever its connections with them. It partnered with progressive evangelical and popular provocateur Tony Campolo while John Perkins, a black evangelical pioneering local community development, joined its board. World Vision also moved further away from any evangelical identity that could be associated with the conservative direction of Religious Right politics. At times, it risked angering its solid evangelical donor base by challenging aspects of American foreign policy. Once opposed to justice and advocacy as political meddling or ecumenical liberalism, World Vision now saw both as an essential part of its mission.

World Vision's passion for the Palestinian people stimulated one of its earliest advocacy efforts. Having opened an office in the West Bank in 1986, it spoke out against Israel's "oppression" of the occupied territories. World Vision realized its American evangelical donor base often referred to Israel as "the people of God", and "the creation of the Israeli state as the fulfillment of biblical prophecy". Yet it felt, "Failure to speak or act on behalf of the poor... [would] be inconsistent with World Vision's Christian development stance" [123,124]. Appealing to Jesus' own example of speaking truth to power, World Vision opened offices in Washington DC, New York, and Geneva, and began learning how to be Christian stewards of its size and significance.

\section{Evangelicals as the New Internationalists: 1995-Present}

By the 1990s, World Vision claimed to be the "largest privately funded relief-and-development agency in the world" [125]. Yet growth in the 1980s and 1990s paled in comparison to the expansion in the decade after 2000. In 1995, World Vision International's budget stood at 300 million dollars. By 2008, it had grown to 2.6 billion dollars [126]. At one level, World Vision expanded as it continued to move beyond its American and evangelical roots. It chose professional development over missions and international governance over American unilateralism. It also embraced a Christian identity that allowed it to partner across ecumenical, interreligious, and even secular divides. At another level, World Vision grew as global issues caught the popular attention of American evangelicals. Throughout its history, World Vision believed that it served as the vanguard of popular American evangelical social action. But over the past decade, it also returned to engage the local church. It did not offer a 
new message as much as a hope that evangelicals were entering a period that put World Vision at the center of a new mainstream of international humanitarianism.

World Vision's rise reflected the growth of fellow Christian relief, development, and mission agencies. Sociologist of religion Robert Wuthnow claimed that American Christians now spent four billion dollars annually on overseas ministries, a fifty percent increase over the past decade. Career missionaries and short-term mission trips continued to multiply, evangelical engagement in foreign policy issues intensified, and the size of almost every faith-based relief and development agency ballooned [127].

Most evangelicals, like most Americans, still paid more attention to domestic issues than to international affairs [128]. Grassroots political organizations rallied evangelicals around local political issues and national elections, but a new generation of evangelicals looked at global issues without rehashing old debates over evangelism and social action. The longtime evangelical activist Ron Sider described the trend as a genuine shift:

The bitter battle between conservative Christians who emphasize evangelism and liberal Christians who stress social action that weakened the church for much of this century has largely ended. Increasingly, most agree that Christians should combine the Good News with good works and imitate Jesus' special concern for the poor [129].

As more evangelicals found themselves drawn to "international issues and geopolitical inequity", others voices sought to label the old evangelical dichotomy an "historical footnote" [130].

Alongside World Vision, organizations like Compassion International and Samaritan's Purse are now ubiquitous in evangelical circles. One of the most popular among young evangelicals is International Justice Mission (IJM), founded by former civil rights attorney Gary Haugen in 1997 to fight child exploitation and global sex trafficking. IJM's core mission is to "stand against violent oppression in response to the Bible's call to justice (Isaiah 1:17): Seek justice, rescue the oppressed, defend the orphan, and plead for the widow" [131]. Haugen saw IJM as an expression of "an evangelical social gospel". He knew that "twenty-five years ago, IJM couldn't have made this kind of progress. Previous generations [of evangelicals] thought the social gospel was a distraction to spiritual concerns" [132]. Now he claimed that evangelicals "under thirty", understood that "you can still be orthodox... and take action" [133].

Other agencies like Micah Challenge emerged to enlist evangelical support in conjunction with the United Nations' Millennium Development Goals (MDGs) pledging to halve global poverty by 2015 [134]. In 2004, World Vision joined alongside other humanitarian agencies, celebrities like U2 frontman Bono, and the Bill and Melinda Gates Foundation to launch the ONE campaign to end extreme poverty and the global AIDS epidemic. Young evangelicals bought "Make Poverty History" wristbands and attended benefit concerts in droves. Times had changed. Few stopped to think about distinctions between structural injustice and individual salvation or whether poverty was a religious or secular issue.

Even many traditional mission agencies have adapted principles from the development organizations. Wycliffe Bible Translators now have micro-finance programs. Denominations, local congregations, evangelical icons, and megachurch pastors have also followed suit. In the past, Rick Warren, megachurch pastor of Saddleback Church in southern California, seemed an unlikely champion 
for humanitarianism. But through the efforts of his wife Kay Warren and her work with World Vision, he soon confessed: "I have been so busy building my church that I have not cared about the poor" [135]. His main focus had centered on church growth and personal discipleship, but after visiting Africa, he felt God calling him to "the cause of ending global poverty" [136]. Once forced to apologize for the possibility of Christian development, humanitarian agencies like World Vision now carry the torch for evangelicals eager to partner with the likes of Bono, Bill Gates, and the United Nations in a broadened civil society.

\section{Conclusions}

With growing evangelical diversity, designations such as "left" and "right" continue to mean less and less without explanation and qualification. A growing number of evangelicals are unwilling to self-describe in either camp. Dissatisfied with the way Christians have engaged in the public sphere in the past, they see their faith as something more than a blueprint for a particular political ideology [137,138]. Given evangelicals' "entrepreneurial quality" [35] new developments like the emergent church or new monasticism have grown out of American evangelicalism as they sought new language for articulating and new ways of practicing their faith $[139,140]$. Yet, the larger shift among evangelicals today is evident far beyond these smaller movements just as it outgrew the networks of self-described progressive evangelicals several decades earlier.

While the agenda of a progressive evangelicalism defined by the likes of Jim Wallis, Tony Campolo, or Ron Sider has retained a voice within American evangelicalism, I argue that the evolution of an American evangelical internationalism has produced a more lasting impact. The growth of evangelical relief and development agencies alone do not explain this shift, but they illustrate how American evangelicals' exposure to global need and interaction with a complex global Christianity has led a broad spectrum of evangelicals to redraw past boundary lines to include engaging many of the social issues they once ignored.

As the largest of the evangelical relief and development organizations, World Vision serves as a good case study. It prided itself in working across traditional boundaries while keeping a foot in multiple worlds. If some American evangelicals initially viewed World Vision's work as out of step with traditional theological and missionary outlooks, the organization saw itself as out ahead of the pack. Its interactions with both relief and development peers as well as diverse Christian constituencies demonstrated that there was not a single approach to faith-based humanitarianism-nor a single evangelicalism. That diversity remains in evangelical relief and development today. While leading agencies like World Vision, Samaritan's Purse, Compassion International, and Food for the Hungry share the support of American evangelicals, they do not always share the same approach in their programs. To be clear, there are significant differences to explore, but pointing to the explosive growth of evangelical relief and development agencies over the past forty years illustrates an important overall trend. As more American Christians embrace a global vision that leads them to transcend the traditional theological and political divisions that have led sociologists to talk of a "culture war", a broadening middle ground and practical ecumenism might be emerging. World Vision's evolution may foreshadow the future of a growing stream of evangelical humanitarianism, and perhaps the escalation of global engagement will be the stimulus. 


\section{Acknowledgements}

I wish to thank Brantley Gasaway for the invitation to contribute this article to an important conversation. I am also grateful for the helpful comments of my peer reviewers. A number of groups provided financial support for this project. I am grateful for the support of the Institute for the Study of American Evangelicals at Wheaton College, the Louisville Institute, and the Lake Institute on Faith and Giving for their support. Special thanks to World Vision who allowed me access to their archives. Thanks as well as to dozens of staff who made time for my questions and proved willing to share their stories and perspectives with me.

\section{References and Notes}

1. "Defining 'Evangelical' in Polling and Research: Are We Speaking the Same Language?" Grey Matter Research and Consulting, 2008. http://greymatterresearch.com/index_files/Grey_Matter_ Report_Defining_Evangelicals_in_Research.pdf (accessed on 8 May 2012).

2. Historians of evangelicalism have highlighted the diversity within evangelicalism for decades through continued debates over evangelicalism's definition. See later section on defining evangelicalism. Sociologists have also debated how to define the term. Conrad Hackett, and D Michael Lindsay. "Measuring Evangelicalism: Consequences of Different Operationalization Strategies." Journal for the Scientific Study of Religion 47 (2011): no. 3, 499-514.

3. Marcia Pally. The New Evangelicals: Expanding the Vision of the Common Good. Grand Rapids: Eerdmans, 2011.

4. David P. Gushee. The Future of Faith in American Politics: The Public Witness of the Evangelical Center. Waco: Baylor University Press, 2008.

5. David P. Gushee, ed. A New Evangelical Manifesto: A Kingdom Vision for the Common Good. St. Louis: Chalice Press, 2012.

6. Dan Cox. "Pew Forum: Young White Evangelicals: Less Republican, Still Conservative." http://www.pewforum.org/Politics-and-Elections/Young-White-Evangelicals-Less-Republican-StillConservative.aspx (accessed on 14 June 2012).

7. David R. Swartz. "The Evangelical Left and the Future of Social Conservatism." Society 49 (2011): 54-60.

8. Pew Forum on Religion and Public Life. "Religion and the Issues: Results from the 2010 Annual Religion and Public Life Survey.” 17 September 2010. http://www.pewforum.org/Politics-andElections/Few-Say-Religion-Shapes-Immigration-Environment-Views.aspx (accessed on 26 July 2012).

9. Nicholas D. Kristof. "Following God Abroad." The New York Times, 21 May 2002. http://www.nytimes.com/2002/05/21/opinion/following-god-abroad.html?pagewanted=2.

10. Nicholas D. Kristof. "Evangelicals a Liberal Can Love.” The New York Times, 3 February 2008. http://www.nytimes.com/2008/02/03/opinion/03kristof.html.

11. Nicholas D. Kristof. "Learning From the Sin of Sodom." The New York Times, 28 February 2010. http://www.nytimes.com/2010/02/28/opinion/28kristof.html?emc=eta1. 
12. Joseph Loconte, and Michael Cromartie. "Let's Stop Stereotyping Evangelicals." The Washington Post, 8 November 2006. http://www.washingtonpost.com/wp-dyn/content/ article/2006/11/07/AR2006110701228.html.

13. For a history of the evangelical left see David R. Swartz. Moral Minority: The Evangelical Left in an Age of Conservatism. Philadelphia: University of Pennsylvania Press, 2012.

14. For a comprehensive history of the Christian Right, see Daniel K Williams. God's Own Party: The Making of the Christian Right. New York: Oxford University Press, 2010.

15. The six are World Vision, Feed the Children, MAP International, Compassion International, Food for the Hungry, and Christian Aid Ministries. The only one not primarily developmentoriented is Wycliffe Bible Translators, but even it has a growing ministry in relief/development. Statistics based on revenues from 1990s.

16. Michael Hamilton. The Financing of American Evangelicalism since 1945. In More Money, More Ministry: Money and Evangelicals in Recent North American History, edited by Larry Eskridge, Mark Noll. Grand Rapids: Eerdmans, 2000, 104-140.

17. In 1946, the revenue shares of faith-based relief and development NGOs were $64 \%$ Jewish, $16 \%$ Catholic, 7\% Ecumenical Christian, 5\% Evangelical, 4\% Mainline Protestant, and 3\% FaithFounded Christian. In 2004, the percentages were almost reversed: 41\% Evangelical, 28\% FaithFounded, 13\% Catholic, 7\% Jewish, 6\% Ecumenical, 4\% Mainline. In addition, while secular organizations made up the vast majority of development aid in the 1960s-1970s, now Christian NGOs account for over $50 \%$.

18. Rachel M. McCleary. Global Compassion: Private Voluntary Organizations and U.S. Foreign Policy Since 1939. New York: Oxford University Press, 2009.

19. McCleary, 25-34. Its 2.6 billion dollars in 2008 revenue dwarfed other religious NGOsevangelical or not. By 2005, it was the second largest of all INGOs Food for the Poor was third, Catholic. Relief was fifth, CARE sixth, Feed the Children — seventh, MAP International—ninth, and Samaritan's Purse-tenth.

20. David W. Bebbington. Evangelicalism in Modern Britain: 1730s to 1980s. Grand Rapids: Baker Books, 1989.

21. Timothy Larsen. Defining and Locating Evangelicalism. In The Cambridge Companion to Evangelical Theology, edited by Timothy Larsen, Daniel J. Treier. Cambridge: Cambridge University Press, 2007, 1-14.

22. Douglas A. Sweeney. "Evangelical: What's In a Word?" In The American Evangelical Story: A History of the Movement. Grand Rapids: Baker Academic, 2005, 17-26.

23. George M. Marsden. "The Evangelical Denomination." In Evangelicalism and Modern America. Grand Rapids: Eerdmans, 1984, vii-xix.

24. Timothy Smith. Revivalism and Social Reform. Nashville: Abingdon Press, 1957.

25. Timothy Smith. "The Evangelical Kaleidoscope and the Call to Christian Unity." Christian Scholar's Review 15 (1986): no. 2, 125-40.

26. Randall Balmer. Mine Eyes Have Seen the Glory. New York: Oxford University Press, 2006.

27. Dayton Donald, and Robert Johnston. The Variety of American Evangelicalism. Knoxville: University of Tennessee Press, 1991. 
28. Donald W. Dayton. "The Search for the Historical Evangelicalism: George Marsden's History of Fuller Seminary as a Case Study." Christian Scholar's Review 23 (1993): no. 1, 12-33.

29. George Marsden. "Response to Donald Dayton." Christian Scholar's Review 23 (1993): no. 1, 34-43.

30. Douglas A. Sweeney. "Historiographical Dialectics: On Marsden, Dayton, and the Inner Logic of Evangelical History " Christian Scholar's Review 23 (1993): no. 1, 48-52.

31. Douglas A. Sweeney. "The Essential Evangelicalism Dialectic: The Historiography of the Early Neo-Evangelical Movement and the Observer-Participant Dilemma." Church History 60 (1991): no. $1,70-84$.

32. Joel Carpenter. "The Scope of American Evangelicalism: Some Comments on the DaytonMarsden Exchange." Christian Scholar's Review 23 (1993): no. 1, 53-61.

33. Matthew A. Sutton. "'Between the Refrigerator and the Wildfire': Aimee Semple McPherson, Pentecostalism, and the Fundamentalist-Modernist Controversy." Church History 72 (2003): no. 1, 159-188.

34. Jon R. Stone. On the Boundaries of American Evangelicalism: The Postwar Evangelical Coalition. New York: St. Martin's Press, 1997.

35. Nathan Hatch. "Response to Carl Henry." In Evangelical Affirmations, edited by Kenneth Kantzer, Carl Henry. Grand Rapids: Academie Books, 1990, 97.

36. Brian Stanley. The World Missionary Conference, Edinburgh 1910. Grand Rapids: Eerdmans, 2009.

37. Gerald H. Anderson. "American Protestants in Pursuit of Mission: 1886-1986." International Bulletin of Missionary Research 12 (1988): 104.

38. William Hutchison. Errand to the World: American Protestant Thought and Foreign Missions. Chicago: University of Chicago Press, 1987, 146-175.

39. James A. Patterson. The Loss of a Protestant Missionary Consensus: Foreign Missions and the Fundamentalist-Modernist Conflict." In Earthen Vessels: American Evangelicals and Foreign Missions, edited by Joel Carpenter, Wilbert R. Shenk. Grand Rapids: Eerdmans, 1990, 73-91.

40. Robert T. Coote. "The Uneven Growth of Conservative Evangelical Missions." International Bulletin of Missionary Research 6 (1982): no. 3, 118-123.

41. Mark Noll. The New Shape of World Christianity: How American Experience Reflects Global Faith. Downers Grove: IVP Academic, 2009, 82-85.

42. Carl F.H. Henry. The Uneasy Conscience of Modern Fundamentalism, 1947. In Two Reformers of Fundamentalism, Harold John Ockenga and Carl F.H. Henry, edited by Joel A. Carpenter. New York: Garland Publishing, Inc., 1988.

43. Ibid, p. 32.

44. Ibid, p. 68.

45. Henry's move prefigured historians like Timothy Smith's efforts to reclaim the enormous social activity of antebellum evangelicals. Timothy Smith. Revivalism and Social Reform in MidNineteenth Century America. New York: Abingdon Press, 1957.

46. Ibid, p. 87.

47. CARE was the only secular INGO breaking the top eight largest INGOs in 1950 and 1960. McCleary, 25-28. 
48. J. Bruce Nichols. The Uneasy Alliance: Religion, Refugee Work, and U.S. Foreign Policy. New York: Oxford University Press, 1988, 10.

49. World Relief articulated its identity against other mainstream agencies even more clearly: "Why does NAE have its own relief agency - NAE relief is different - it is Christian relief. With every gift of food and clothing distributed overseas by reliable established evangelical Christians, goes a Gospel message in printed from. It is not enough for Christians to relieve the physical suffering of men and women and children, while their souls go to hell. On the other hand, evangelicals cannot preach Christ to people whose stomachs are empty and whose bodies are weak from exposure to cold when Christians have it within their power to feed and clothe them. Through the food, clothing and Gospel testimony distributed by NAE's World Relief Commission every year, thousands and thousands of people find relief from acute physical suffering and spiritual starvation." United Evangelical Action, 15 March 1957, p. 36.

50. Larry Tise. A Book About Children: The World of Christian Children's Fund, 1938-1991. Falls Church: Hartland Publishing, 1993.

51. The agency was renamed Compassion, Incorporated in 1963. In 1965, founder Everett Swanson died. Gary F. VanderPol. "The Least of These: American Evangelical Parachurch Missions to the Poor, 1947-2005.” Doctoral, Boston University, 2010, 127-130.

52. Richard Quebedeaux coined the term "establish evangelicals" in the 1970s to identity one strand of an increasingly diverse American evangelicalism. He identified Graham, Henry, Ockenga, and most of the leading figures in the 1960s as establishment evangelicals in contrast to a new generation of more progressive "young evangelicals." Richard Quebedeaux. The Young Evangelicals. New York: Harper and Row, 1974, 50-51.

53. Beginning publication in 1956, Christianity Today surpassed the circulation of the Christian Century in only four years. Timothy Yates. Christian Mission in the Twentieth Century. Cambridge: Cambridge University Press, 1994, 195-196.

54. "What Protestant Ministers Believe." Christianity Today 31 March, 1958, 30; "The American Clergy and Basic Truths.” Christianity Today, 10 October 1960. In 1958, Christianity Today's own poll found Protestant ministers classified themselves as: $35 \%$ fundamentalist; $39 \%$ conservative; $12 \%$ neo-orthodox; $14 \%$ liberal.

55. Darren Dochuk. From Bible Belt to Sunbelt: Plain-Folk Religion, Grassroots Politics, and the Rise of Evangelical Conservatism. New York: W.W. Norton, 2011.

56. John Turner. Bill Bright \& Campus Crusade for Christ: The Renewal of Evangelicalism in Postwar America. Chapel Hill: University of North Carolina Press, 2008.

57. Billy Graham. "The Event of the Year." Christianity Today 1 January 1965, 45.

58. William Inboden. Religion and American Foreign Policy, 1945-1960: The Soul of Containment; Cambridge: Cambridge University Press, 2008, 85-87.

59. F. Dale Bruner. “A New Strategy: Statesmanship in Christian Missions.” Christianity Today, 1 August 1960, p. 3.

60. Rachel M. McCleary. "Private Voluntary Organizations Engaged in International Assistance, 1939-2004.” Nonprofit \& Voluntary Sector Quarterly 37 (2008): 523-524. Mainline Protestant agencies got 53 percent of their budgets from the federal government between 1955 and 1965 while Catholic Relief Services averaged 67 percent of its revenue from Washington. Evangelical 
organizations received 33 percent of their revenue from the federal government during the same period. McCleary includes the Mennonite Central Committee and World Relief as the two largest evangelical organizations.

61. "Bob Pierce Reports: Total Loss for Thousands in Vietnam." World Vision Frontline News. August 1965 (WVI Central Records).

62. First published by Wheaton's Tyndale House in 1971, The Living Bible was the best-selling book in America in 1972-3. Lindsey's Late Great Planet Earth produced an entire new genre of books predicting end times scenarios in current events. (It is a precursor to the popular Left Behind series). Originally published by evangelical Zondervan, its success led to secular Bantam press republishing it in 1973.

63. He worried responses to the current challenges in theology, socio-political involvement, and ecumenism would further fracture the evangelical voice. Carl Henry. Evangelicals at the Brink of Crisis, Significance of the World Congress on Evangelism. Waco: Word Books, 1967.

64. David R. Swartz. "Left Behind: The Evangelical Left and the Limits of Evangelical Politics, 1965-1988." Doctoral. University of Notre Dame, South Bend, IN, USA, 2008, p. 360. Swartz analyzes the specific demographics of younger evangelicals: "First, its members were educated... Second, despite efforts to recruit African-Americans, its members were overwhelmingly white...Third, its members worked in the social service sector... Fourth, its members disproportionately lived in cities. In short, progressive evangelicals seemed to be prototypical members of the "knowledge class."

65. Samuel Escobar. "Social Concern and World Evangelism." In Christ the Liberator, edited by John R. Stott. Downers Grove: InterVarsity Press, 1971, 107-108.

66. Keith and Gladys Hunt. For Christ and the University: The Story of InterVarsity Christian Fellowship of the U.S.A./1940-1990. Downers Grove: Inter Varsity Press, 1991, 274-278.

67. Brantley W Gasaway. "An Alternative Soul of Politics: The Rise of Contemporary Progressive Evangelicalism.” Doctoral, University of North Carolina, 2008, pp. 65-67.

68. Carl Henry. A Plea for Evangelical Demonstration. Grand Rapids: Baker Book House, 1971, 22.

69. Gasaway, pp. 51-61.

70. Ibid, pp. 39-49.

71. Jim Wallis. "Post-American Christianity." Post-American, 1971 Fall, 3.

72. Ronald J. Sider. "An Historic Moment for Biblical Social Concern." In The Chicago Declaration. Carol Stream: Creation House, 1973, 31-33.

73. Marjorie Hyer. "Social and Political Activism Is Aim of Evangelical Group." Washington Post, 30 November 1973, D17.

74. Watergate: Interview with Graham. Christianity Today, 4 January 1974, pp. 17-18.

75. C. Peter Wagner. "Evangelism and Social Action in Latin America." Christianity Today, 7 January 1965, pp. 10-12.

76. As convener of the Congress, Billy Graham defined the three purposes of the Congress as discovering the best techniques for world evangelization, defining the relationship between evangelism and social responsibility, and seeking evangelical unity. Billy Graham. "Why Lausanne?" In Let the Earth Hear His Voice: Official Reference Volume, Papers and Responses, 
International Congress on World Evangelization, edited by J.D. Douglas, Minneapolis: World Wide Publications, 1975, 26.

77. Douglas. Let the Earth Hear His Voice, pp. 4-5. Section 5 that addressed social concern was by far the longest section of the Lausanne Covenant.

78. Samuel Escobar. "Evangelism and Man's Search for Freedom, Justice, and Fulfillment." In Let the Earth Hear His Voice, edited by J.D. Douglas. Minneapolis: World Wide Publications, 1975, 304-305.

79. J.D. Douglas, ed. "Theology Implications of Radical Discipleship." In Let the Earth Hear His Voice. Minneapolis: World Wide Publications, 1975, 1294-1296.

80. René C. Padilla. The New Face of Evangelicalism: An International Symposium on the Lausanne Covenant. Downers Grove: InterVarsity Press, 1976.

81. Samuel Escobar. "A Movement Divided: Three Approaches to World Evangelization Stand in Tension with One Another." Transformation 8 (1991): 7-13.

82. Robert Hunt. "The History of the Lausanne Movement, 1974-2010." International Bulletin of Missionary Research 35 (2011): 81-84.

83. Waldron Scott. "The Significance of Pattaya." Missiology 9 (1981): 57-76.

84. Ronald Sider. Lifestyle in the Eighties: An Evangelical Commitment to Simple Lifestyle. Philadelphia: Westminster Press, 1982.

85. John R.W. Stott. "Twenty Years after Lausanne: Some Personal Reflections.” International Bulletin of Missionary Research 19 (1995): 50-55.

86. The CRESR conference went on to define social action and evangelism as equal partners. It described the relationship as "two blades of a pair of scissors or the two wings of a bird." In "Evangelism and Social Responsibility: An Evangelical Commitment." Lausanne Occasional Paper 21, http://www.lausanne.org/en/documents/lops/79-lop-21.html (accessed on 12 November 2011).

87. William Newel. Director of World Vision Canada. In World Vision 1973-1974 Annual Report (WVI Central Records).

88. Arne Bergstrom. Interview with author. Federal Way, WA. 16 November 2010.

89. World Vision's research noted 70 percent of evangelicals lived in the developing world by the turn of the twenty-first century. Bryant L Myers, Don Brandt, and Alan Whaites. Global Context for Action 2001. Monrovia: World Vision, 2001.

90. Carl Henry. Evangelicals in Search of Identity. Waco: Word Books, 1976, 22.

91. Harold Lindsell. The Battle for the Bible. Grand Rapids: Zondervan, 1976.

92. Donald W. Dayton. "The Battle for the Bible: Renewing the Inerrancy Debate." Christian Century, 10 November 1976, 976-980.

93. W. Stanley Mooneyham. "The World: Color It Gray." Address given to Religion Newswriters' Association, Anaheim, CA. 5 July 1975 (WVI Central Records).

94. W. Stanley Mooneyham. What Do You Say to a Hungry World? Waco: Word Books, 1975, 31-32.

95. H. Daniel Friberg. "Shifting Balances: Missionaries or Marines?” Christianity Today, 3 August 1962, pp. 3-5.

96. “Hatfield Urges National Fasting Day.” Washington Post, 26 November 1974, A4. 
97. “Joint Senator Hatfield and World Vision Press Release." 26 November 1974. (WVI Central Records).

98. For critiques of these practices of fundraising through images of suffering, see Alexander De Waal. Famine Crimes: Politics \& the Disaster Relief Industry in Africa. Bloomington: Indiana University Press, 1997.

99. Also see, Susan D. Moeller. Compassion Fatigue: How the Media Sell Disease, Famine, War And Death. New York: Routledge, 1999.

100. Robert Booth Fowler. A New Engagement: Evangelical Political Thought, 1966-1976. Grand Rapids: Eerdmans, 1982.

101. Ed Norman. "Our Hunger Program-Not Either/or but Both/And.” World Vision, May 1975, p. 16.

102. Mooneyham. What Do You Say to a Hungry World? Waco: Word Books, 1975, 137-150.

103. Ibid., p. 122.

104. VanderPol, p. vii.

105. Mooneyham. "Where Did the Hunger Crisis Go?" World Vision, October 1976, pp. 10-11. World Vision reported its 1975 income was up 57 percent over the previous year, and it also claimed its hunger appeals led to increased contributions to Church World Service, Food for the Hungry, and World Relief as well.

106. Ken Waters. "How World Vision Rose From Obscurity To Prominence: Television Fundraising, 1972-1982.” American Journalism 15 (1998): 69-94.

107. Linda D. Smith. "An Awakening of Conscience: The Changing Response of American Evangelicals Toward World Poverty.” Doctoral, American University, 1987, p. 95.

108. Smith, 1104-108, 312-316 (ft. 104). Nine new evangelical organizations were founded in the 1970s. Five had been founded in both the 1950s and 1960s. Evangelical relief and development agencies grew from income of $\$ 21.8$ million in 1969/1970 to \$190 million in 1981/1982 (a ninefold increase). Overall evangelical giving to Third World poverty grew over the decade from $\$ 147.7$ to $\$ 622$ million.

109. Ronald Sider. Rich Christians in an Age of Hunger. Downers Grove: InterVarsity Press, 1977. Swartz, 'Left Behind', 143-146.

110. Ron Sider. "Toward a Theology of Community Development." Development Assistance Services Conference (DAS), Haiti, 1978. Folder 7, Box 32, Collection 165, EFMA Records. Archives of the Billy Graham Center, Wheaton, IL.

111. Carl F.H. Henry, and Robert Lincoln Hancock, eds. The Ministry of Development in Evangelical Perspective: A Symposium on the Social and Spiritual Mandate. Pasadena: William Carey Library, 1979.

112. Ronald Sider, ed. Evangelicals and Development: Toward a Theology of Social Change. Philadelphia: Westminster Press, 1982.

113. AERDO charter members were World Relief; Food for the Hungry, Compassion, World Concern, MAP international, Institute of International Development, Inc, and World Vision International.

114 McCleary. Global Compassion. 134.

115. Ken Woodward. “Born Again!” Newsweek, 25 October 1976, pp. 68-78.

116. “Back to that Old-Time Religion.” Time, 26 December 1977, pp. 52-58. 
117. "Protestants: Away From Activism and Back to the Basics." US News \& World Report, 11 April 1977, p. 58.

118. Mooneyham. "Some Thoughts about the Bandwagon." World Vision, May 1978, p. 23.

119. Sue Avery. "World Vision-Food and Faith." Los Angeles Times, 25 December 1980, SG1.

120. "Back to that Old-time Religion." Time, 26 December 1977, 58.

121. Graeme Irvine. Best Things in the Worst Times: An Insider's View of World Vision. Wilsonville: BookPartners, 1996, pp. 116-117.

122. In a survey of staff in 1999, World Vision International found $57 \%$ identified as evangelical, $19 \%$ as mainline, $16 \%$ as Catholic, $1 \%$ as Orthodox, and $7 \%$ as other. "The Commission of the Church Report.” 2002 (WVI Central Records). In an informal poll of World Vision U.S. staff, it estimated $68 \%$ identified as evangelical/Pentecostal and only $6 \%$ as mainline. Cindy Waple. Interview by author. 16 Nov. 2010, Federal Way, WA. Presently, World Vision U.S. uses the five divisions employed by the ecumenical organization Christian Churches Together (Protestant, Roman Catholic, evangelical, Orthodox, and Pentecostal). The 2002 World Vision International "Commission of the Church Report" does not clarify if Pentecostals are included in the evangelical category or who is included within the "other."

123. Graeme Irvine. "Beyond Anger.” Together, July-September 1990, pp. 1-4.

124. "World Vision Advocacy Policy Statement." 1991.

125. Robert Seiple. "De-Seiple-ing World Vision." Christianity Today, 15 June 1998, pp. 49-51.

126. World Vision International Annual Reports, 1995-2008 (WVI Central Records).

127. Robert Wuthnow. Boundless Faith: The Global Outreach of American Churches. Berkeley: University of California Press, 2009, 1.

128. World Vision found that only one-quarter of donors to nonprofits gave to international agencies. The focus on poverty remained domestic. Evangelicals were actually twice as likely to give to international causes as the average population (50\% to 25\%). "Perceptions of Poverty: Baseline." July 1999, study conducted by Barna Research and commissioned by World Vision (WVUS Archives).

129. Ronald Sider. Just Generosity: A New Vision for Overcoming Poverty in America. Grand Rapids: Baker Books, 1999, 217.

130. Bryant L. Myers. Walking With the Poor: Principles and Practices of Transformational Development. 2nd ed. Maryknoll: Orbis Books, 2011, 48-49.

131. "International Justice Mission: Who We Are." http://www.ijm.org/who-we-are (accessed on 22 April 2012).

132. Michael D. Lindsay. Faith in the Halls of Power: How Evangelicals Joined the American Elite. New York: Oxford University Press, 2007, 45.

133. Allen Hertzke. Freeing God's Children: The Unlikely Alliance for Global Human Rights. Lanham: Rowman \& Littlefield, 2004, 319.

134. Micah Challenge takes its name from the biblical passage, Micah 6:8, "He has shown you O man what is good. And what does the Lord require of you? To act justly, and to love mercy, and to walk humbly with your God." 
135. Marc Gunther. "Will Success Spoil Rick Warren?" Fortune, 2005. Available online: http://money.cnn.com/magazines/fortune/fortune_archive/2005/10/31/8359189/index.htm (accessed on 25 April 2012).

136. Holly Lebowitz Rossi. "Rick Warren Publicly Pursuing Programs against World Poverty." Christian Century, 12 July 2005, 122, pp. 15-16.

137. Lisa Sharon Harper. "A Call to Transform Politics." http://www.qideas.org/blog/a-call-totransform-politics.aspx (accessed on 10 September 2012).

138. Lisa Sharon Harper, and David C. Innnes. Left, Right, \& Christ: Evangelical Faith in Politics. Boise: Russell Media, 2011.

139. Michael Clawson. "Misión Integral and Progressive Evangelicalism: The Latin American Influence on the North American Emerging Church.” Religions 3 (2012): 790-807.

140. Shane Claiborne. The Irresistible Revolution: Living as an Ordinary Radical. Grand Rapids: Zondervan, 2006.

(C) 2012 by the author; licensee MDPI, Basel, Switzerland. This article is an open access article distributed under the terms and conditions of the Creative Commons Attribution license (http://creativecommons.org/licenses/by/3.0/). 